\title{
Water Quality Index and Correlation Study for the Assessment of Water Quality and its Parameters of Yercaud Taluk, Salem District, Tamil Nadu, India
}

\author{
P. LILLY FLORENCE ${ }^{1 *}$, A. PAULRAJ ${ }^{2}$ and T. RAMACHANDRAMOORTHY ${ }^{3}$ \\ ${ }^{1}$ Department of Chemistry, M.A.M. School of Engineering, Tiruchirappalli-621105, India \\ ${ }^{2}$ Department of Chemistry, St.Joseph's College (Autonomous), Tiruchirappalli-620002, India \\ ${ }^{3} \mathrm{PG}$ and Research Department of Chemistry, Bishop Heber College (Autonomous), \\ Tiruchirappalli - 620 017, Tamil Nadu, India \\ lilly_jeneliya@yahoo.co.in
}

Received 7 May 2012 / Accepted 17 May 2012

\begin{abstract}
Groundwater samples of bore wells (BW), open wells (OW), Hand Pumps (HP), lakes, falls and streams collected from different locations in Yercaud Taluk in Salem District, Tamil Nadu were analyzed for their physicochemical characteristics. The ground water samples were studied during pre-monsoon (June-July 2010) and post-monsoon (December 2010-January 2011) seasons from 25 different villages. The present study was undertaken to characterize the physicochemical parameters such as temperature, pH, Total Alkalinity (TA), Electrical Conductivity (EC), salinity, Calcium Hardness (CH), Magnesium Hardness (MH), Total Hardness (TH), Total Dissolved Solids (TDS), Total Suspended Solids (TSS), Total Solids (TS) and fluoride. Each parameter was compared with its standard permissible limit as prescribed by World Health Organization (WHO). The Water Quality Index (WQI) reflected that most of the samples are of good and excellent quality. The Karl Pearson Correlation matrix has approved the influence of $\mathrm{CH}$ on EC, Salinity and TDS with significantly positive correlation. The study reveals that all the villages have hardness within the desirable limit prescribed by WHO.
\end{abstract}

Keywords: Dental fluorosis, Physicochemical parameters, Water Quality Index, Karl-Pearson Correlation, Salem, Yercaud

\section{Introduction}

Groundwater is generally recognized to be good for human consumption and is used as a potential source of drinking water. Agricultural development, urbanization and industrialization are the major causes for all changes in the quality of water ${ }^{1}$. In order to meet the rising water needs, evaluation of water quality is important for allocation to various uses. Only during the last three decades of the twentieth century, the concern for water quality has been exceedingly felt so that, water quality has now acquired as much importance as water quantity ${ }^{2}$. According to $\mathrm{WHO}^{3}$, about $80 \%$ of all the diseases in human beings are caused by contaminated water. Once the groundwater is polluted, its quality cannot be renovated by stopping the pollutants from the source. It is therefore vital to regularly monitor the quality of groundwater. Groundwater pollution by heavy metals has 
been given much attention due to their low biodegradability and toxic effects ${ }^{4,5}$. The water from the sources viz., streams, falls, lake, hand pump, open well and bore well are contaminated with domestic, agricultural and industrial wastes and likely to cause water related diseases ${ }^{6}$. Similarly, Bullard ${ }^{7}$ inferred that polluted surface water always results in an unhealthy socio-economic environment. In this study, physicochemical parameters are determined to draw a conclusion on the quality of water whether it is good or unfit for drinking purpose.

Statistical analysis of physicochemical parameters of water has been reported from the different parts of World and India ${ }^{8-12}$. C. R. Ramakrishnaiah et al. ${ }^{13}$, have assessed the Water Quality Index for the Groundwater in Tumkur Taluk, Karnataka State, India. Linear correlation analysis study of drinking water quality data for Al-Mukalla city, Hadhramout, Yemen was carried out by Sami G. Daraigan et al., ${ }^{14}$ and from this study they showed that all the physicochemical parameters of drinking water in Mukalla city are more or less correlated with each other. Papita Das Saha et al., ${ }^{15}$ have assessed the water quality characteristics of River Ganga at Kolkata Region, India using water quality index and ANN simulation method ${ }^{15}$. Dadolahi - Sohrab et al. ${ }^{16}$. have studied the Water quality index as a simple indicator of watersheds pollution in southwestern part of Iran and from this study it is revealed that quality declined significantly during the dry season. So, an attempt is made to study the physicochemical parameters of water samples taken from Yercaud Taluk in Salem, Tamil Nadu, India.

The main objectives of the study are

- Collection of ground water samples from open wells, bore wells, hand pumps, streams, falls and lakes -Yercaud Taluk, Salem District, Tamil Nadu.

- Analysis of a few quality parameters viz., pH, Total alkalinity, Electrical conductivity, Total solids, Hardness, Fluoride etc., as recommended by World Health Organization.

- To establish the nature of the relationship between the water quality parameters using correlation analysis.

- $\quad$ Assessment of the water quality using water quality index (WQI).

\section{Salient features of the study area}

Salem District in Tamil Nadu, India is geographically situated between the North latitudes $11^{\circ} 14^{\prime}$ to $12^{\circ} 53^{\prime}$ and East longitudes $77^{\circ} 44^{\prime}$ to $78^{\circ} 50^{\prime}$ covering an area about 7905.38 square kilometers. On the Northern side, it is bounded by Dharmapuri District; on the Western side, it is bounded by Erode District; on the Eastern side, it is bounded by Viluppuram District and on the Southern side, it is bounded by Namakkal and Tiruchirappalli Districts. Salem District consists of nine Taluks viz., Attur, Edappadi, Gengavalli, Mettur, Omalur, Salem, Sangagiri and Yercaud. The present study area (Yercaud Taluk) is one of the nine taluks in Salem District.

Yercaud is a hill station situated in Salem District, Tamil Nadu. It is located in the Shervaroys range of hills in Eastern Ghats. The total extent of Yercaud Taluk is $382.67 \mathrm{~km}^{2}$, including reserve forest. It is situated at an altitude of 1515 meters $(4970 \mathrm{ft})$ above the sea level. The yercaud range consists of achaean plutonic rocks of charnockite series and these have weathered into the rugged masses of hills. It is so named owing to the large quantity of trees categorized as a forest near the lake, the name signifying lake forest. A popular tourist destination, Yercaud is also called Jewel of the South. The climate of Yercaud is moderate and pleasant. There is neither a sharp winter nor a roasting summer. Winters are fairly mild, starting in September and ending in December. During winter, the hills are covered in mist. Winters range from $12{ }^{\circ} \mathrm{C}$ to $25^{\circ} \mathrm{C}$ and summers from $16^{\circ} \mathrm{C}$ to $30^{\circ} \mathrm{C}$. Rainfall is $1500-2000 \mathrm{~nm}$. 
The coffee bushes blossom in April and offer a spectacular view. Coffee and citrus fruits, most notably oranges, are grown in abundance, as well as bananas, pears and jackfruit. Spices such as black pepper and cardamom are other crops raised on the coffee estate. Sandal wood, teak and silver oak are rich in this area. It also has an orchidarium run by the Botanical Survey of India. Wild life includes bison, deer, rabbits, hares, foxes, mongoose, squirrels, partridges, snakes, bulbuls, kites, sparrows, swallows and the bird of paradise. The nearest city is Salem, $36 \mathrm{~km}$ away from Yercaud. It is $355 \mathrm{~km}$ from Chennai and $195 \mathrm{~km}$ from Coimbatore. The nearest airports are Salem Airport at $38 \mathrm{~km}$, Tiruchirappalli at $165 \mathrm{~km}$ and Coimbatore at $195 \mathrm{~km}$. The entire Taluk is a Township. Yercaud has population approximately 40,000 people during the 2001 census period $^{17}$.

\section{Experimental}

The water samples were collected from bore wells (BW), open wells (OW), Hand Pumps (HP), lakes, falls and streams of Yercaud Taluk in Salem District, Tamil Nadu during premonsoon (June-July 2010) and post-monsoon (December 2010-January 2011) periods. Of the total 25 water samples, 4 were from bore wells, 5 were from hand pumps, 7 were from open wells, 5 were from falls, 2 were from streams and 2 were from lakes. The samples were collected in sterilized bottles and were analyzed just after the sampling. The analysis was carried out ${ }^{18}$ for various physicochemical parameters such as temperature, $\mathrm{pH}$, Electrical conductivity (EC), Total alkalinity (TA), Salinity (SAL), Calcium hardness (CH), Magnesium hardness (MH), Total hardness (TH), Total dissolved solids(TDS), Total suspended solids (TSS), Total solids (TS) and Fluoride content.

\section{Methodology}

The temperature of water samples was recorded on the spot using thermometer. $\mathrm{pH}$ meter (Systronics digital model 335) was used to determine the hydrogen ion concentration. The samples were analyzed for EC using conductivity meter. Total alkalinity (TA) was estimated by neutralizing with standard $\mathrm{HCl}$ acid. Salinity and total dissolved solids (TDS) were estimated using systronics water analyzer. Total hardness $(\mathrm{TH})$ and calcium hardness $(\mathrm{CH})$ as $\mathrm{CaCO}_{3}$ were determined titrimetrically, using standard EDTA. The calculation of magnesium hardness $(\mathrm{MH})$ was done by subtracting the $\mathrm{CH}$ from $\mathrm{TH}$ value. The fluoride was estimated by SPANDS [2-( $p$-sulphophenylazo) 1,8-dihydroxy-naphthalene - 3,6 - disulphonic acid tri sodium salt), $\mathrm{C}_{16} \mathrm{H}_{9} \mathrm{~N}_{2} \mathrm{O}_{11} \mathrm{~S}_{3} \mathrm{Na}_{3}$ ] colorimetric method $^{18}$.

\section{Statistical analysis}

Statistical analysis was carried out using statistical package for social sciences (SPSSVersion 13). Statistical parameters viz., mean, SD, SE and correlation coefficient for physicochemical parameters. The mean and standard deviations are calculated to know the chemical parameters which are deviating from WHO standard. Correlation analysis measures the closeness of the relationship between chosen variables. If the correlation coefficient is nearer to +1 or -1 , it shows the perfect linear relationship between the two variables. This way analysis attempts to establish the nature of the relationship between the water quality parameters.

\section{Water quality index (WQI)}

Water quality index ${ }^{19}$ expresses overall water quality based on several water quality parameters. Water Quality Index is computed by the following formula 
$\mathrm{WQI}=$ Antilog $\left[\mathrm{SW}_{\mathrm{n}=1}^{\mathrm{n}} \log { }_{10} \mathrm{q}_{\mathrm{n}}\right]$, where, $\mathrm{W}_{\mathrm{n}}$, Weightage $=\mathrm{K} / \mathrm{S}_{\mathrm{n}}$ and $\mathrm{K}$, constant $=1 / \mathrm{S}_{\mathrm{n}=1}^{\mathrm{n}}$ $\left.1 / S_{i}\right), S_{n}$ and $S_{i}$ correspond to the WHO / ICMR standard value of the parameters. Quality rating (q) is calculated as $\mathrm{Q}_{\mathrm{ni}}=\left[\left(\mathrm{V}_{\text {actual }}-\mathrm{V}_{\text {ideal }}\right) /\left(\mathrm{V}_{\text {standard }}-\mathrm{V}_{\text {ideal }}\right)\right] \times 100$, where $\mathrm{q}_{\mathrm{ni}}=$ quality rating of $\mathrm{i}^{\text {th }}$ parameter for a total of $\mathrm{n}$ water samples, $\mathrm{V}_{\text {actual }}=$ value of the water quality parameter obtained from the laboratory analysis, $\mathrm{V}_{\text {standard }}=$ value of the water quality parameter obtained from the standard tables. $\mathrm{V}_{\text {ideal }}$ for $\mathrm{pH}=7$ and for the other parameters it is equivalent to zero.

\section{Results and Discussion}

Season-wise chemical compositions of 12 water samples of Yercaud Taluk, Salem District in the pre-monsoon and post-monsoon seasons are presented in Table 1 and Table 2. Statistical summary of water samples in pre-monsoon and post-monsoon of Yercaud Taluk in Salem District, Tamil Nadu is shown in Table 3.

Table 1. Physicochemical parameters of water samples of Yercaud Taluk in the pre monsoon season

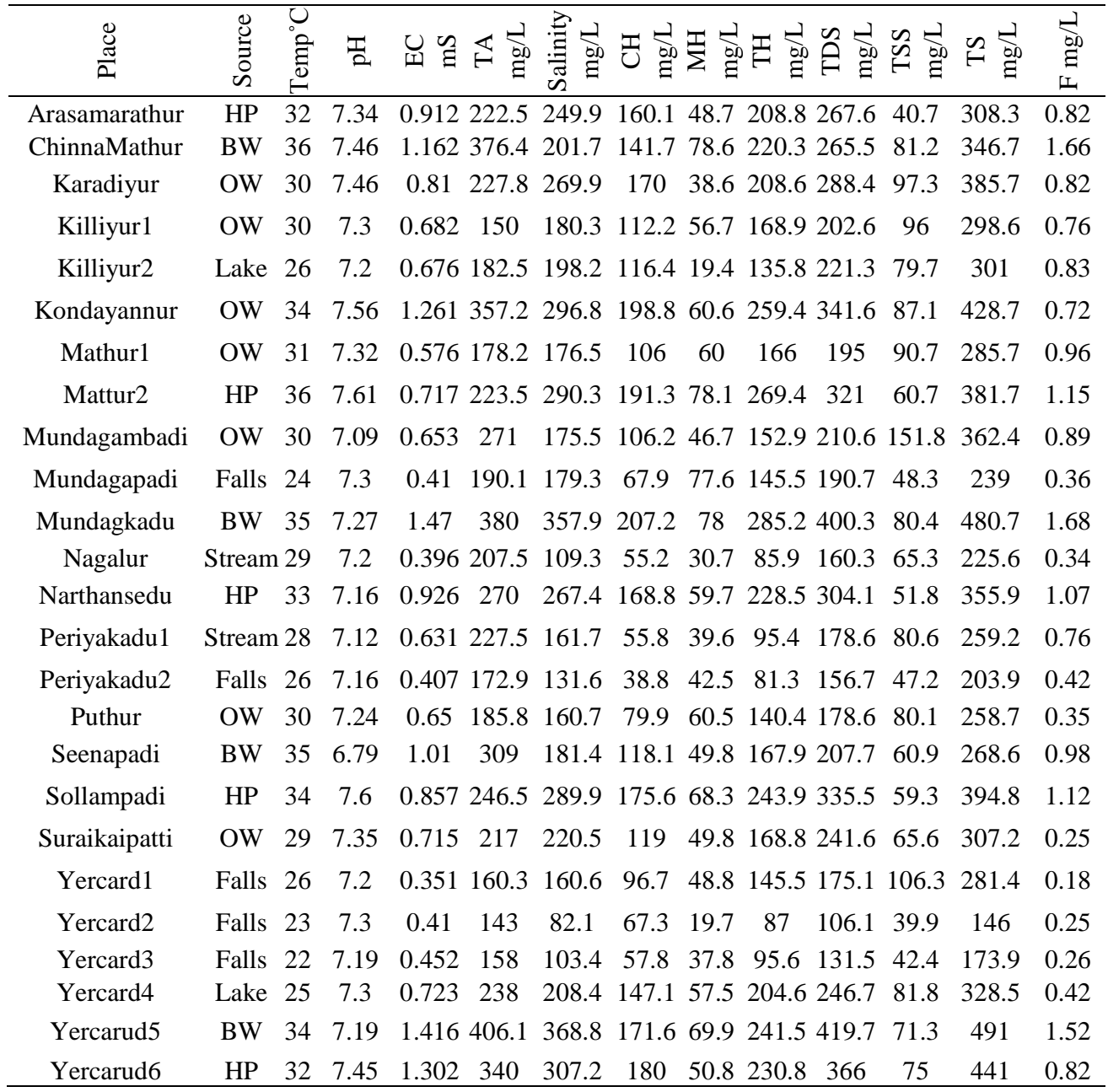


Table 2. Physicochemical parameters of water samples of Yercaud Taluk in the postmonsoon season

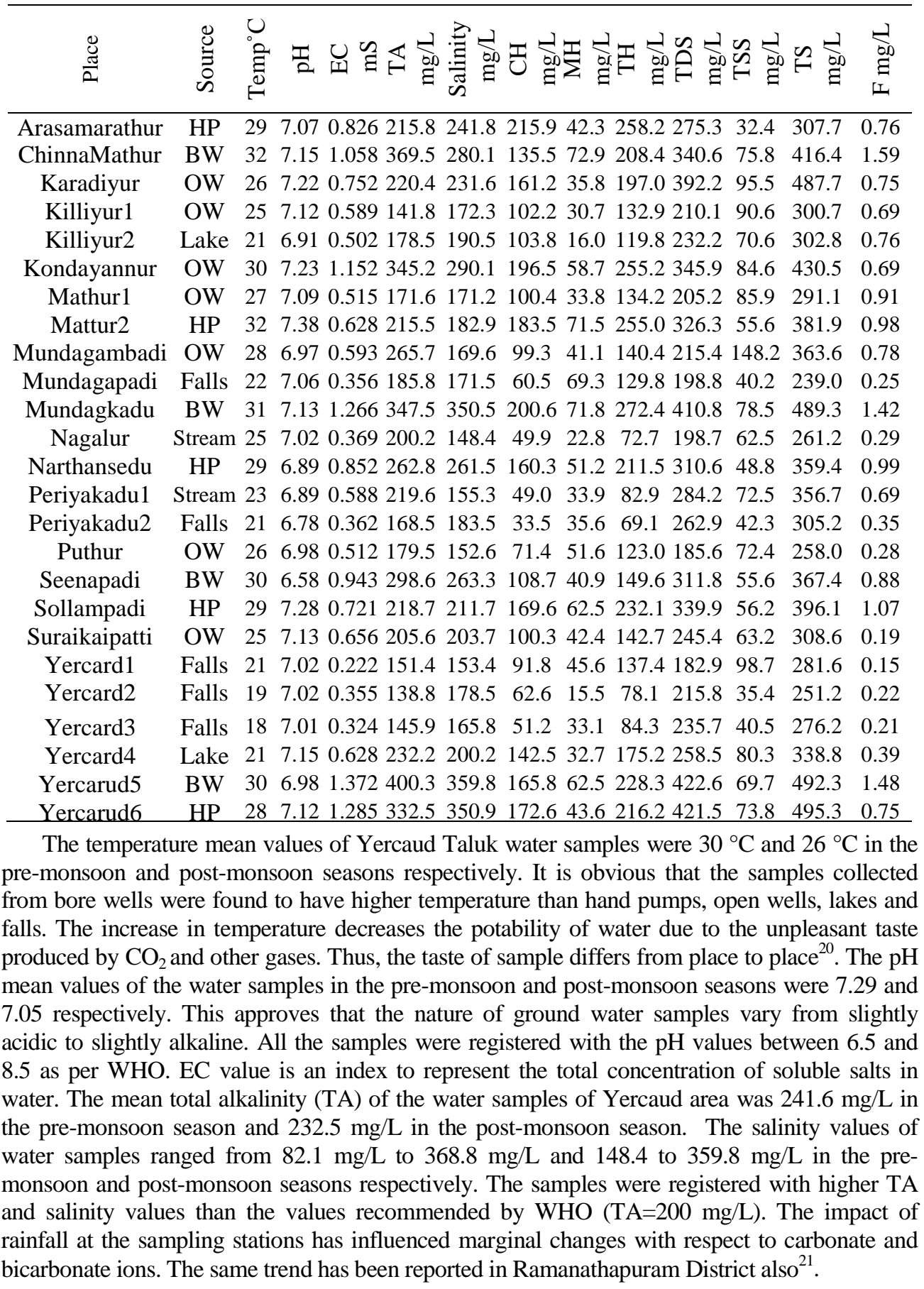


In the pre-monsoon and post-monsoon seasons, $\mathrm{Ca}^{2+}$ was observed with the mean values of $124.4 \mathrm{mg} / \mathrm{L}$ and $131.8 \mathrm{mg} / \mathrm{L}$ respectively. The $\mathrm{Mg}^{2+}$ mean values of the water samples in the pre-monsoon and post-monsoon seasons were $53.1 \mathrm{mg} / \mathrm{L}$ and $44.7 \mathrm{mg} / \mathrm{L}$ respectively. The $\mathrm{Ca}^{2+}$ and $\mathrm{Mg}^{2+}$ concentrations slightly decreased during post-monsoon (except Arasamarathur) when compared to the pre-monsoon. The presence of $\mathrm{CH}$ and $\mathrm{MH}$ in all water samples is more than the recommended limit of WHO $(\mathrm{CH}=75 \mathrm{mg} / \mathrm{L}$; $\mathrm{MH}=30 \mathrm{mg} / \mathrm{L}$ ). The total hardness of the water samples varied between $81.3 \mathrm{mg} / \mathrm{L}$ and $285.2 \mathrm{mg} / \mathrm{L}$ in pre-monsoon and between $72.7 \mathrm{mg} / \mathrm{L}$ and $272.4 \mathrm{mg} / \mathrm{L}$ in post-monsoon.

Most of the ground water samples of Yercaud Taluk were found to be hard (100-300 mg/L) as suggested by Sawyer and Mc Carty $(1967)^{22}$. The ground water samples were observed with the $36 \%$ and $44 \%$ of moderately hard nature in the pre-monsoon season and $64 \%$ and $52 \%$ of hard nature in the post-monsoon season. The hard nature was converted to soft nature in the study area Nagalur $(85.9 \mathrm{mg} / \mathrm{L}$ to $72.7 \mathrm{mg} / \mathrm{L})$ thus revealed the change in the quality of soil when the water table gets raised in the post-monsoon season.

The TDS values of water samples were found within the desirable limit of WHO (i.e.) $500 \mathrm{mg} / \mathrm{L}$. The total ground water samples of study area were registered with $100 \%$ belonging to fresh type (TDS $<1000 \mathrm{mg} / \mathrm{L}$ ) in both pre-monsoon and post-monsoon seasons as per TDS classification given by Fetter ${ }^{23}$.

The fluoride content of the samples varied from $0.2 \mathrm{mg} / \mathrm{L}$ to $1.7 \mathrm{mg} / \mathrm{L}$ and $0.15 \mathrm{mg} / \mathrm{L}$ to $1.6 \mathrm{mg} / \mathrm{L}$ in the pre-monsoon and post-monsoon respectively. Three viz., Chinna Mathur (BW), Mundagkadu (BW) and Yercaud 5 (BW) out of 25 samples in the pre-monsoon season and one (Chinna Mathur) out of 25 samples in the post-monsoon season have exceeded the permissible limit of $1.5 \mathrm{mg} / \mathrm{L}$ (WHO). As reported earlier ${ }^{24}$, the dissolution of fluoride bearing minerals may be contributing the high percentage of fluoride in water samples. In this attempt, the suitable conditions for the dissolution of $\mathrm{CaF}_{2}$ in the potable water are slightly alkaline $\mathrm{pH}$ and moderate EC and being approved by the positive correlation value of $\mathrm{F}-\mathrm{CH}$ ( $\mathrm{r}=0.6663$ in pre-monsoon; $\mathrm{r}=0.5590$ in post-monsoon). 9 samples out of 25 , both in pre-monsoon season and post-monsoon season were observed with fluoride lesser than 0.5 , the desirable limit of WHO. The comparison of fluoride concentration for Yercaud Taluk in pre-monsoon \& postmonsoon seasons reveals that, in general, fluoride ion concentration decreases in postmonsoon as compared to pre-monsoon due to increase in water table. Especially higher concentrations of fluoride were observed in bore well and hand pump water ${ }^{25}$. It was found that the bore well and hand pump water samples (4 bore well water samples and 5 hand pump water samples) contain more fluoride than the open well, lake, falls and stream samples. This is due to the increase in depth, the temperature increases and hence more fluoride gets dissolved from rocks.

The Karl pearson correlation matrix calculated for the water quality parameters is displayed in Table 4 and Table 5 . The parameters, highly interrelated with each other, are EC - Salinity: 0.8442; EC-TDS: 0.8799 and Salinity-TDS: 0.9876. The values account for greater percentage of TDS. In pre-monsoon season and post-monsoon season, the influence of $\mathrm{CH}$ on EC, Salinity and TDS were also observed with significantly positive correlation. The correlation of fluoride with calcium in pre-monsoon has been found with higher positive $r$ value $(0.6663)$ than in post-monsoon $(0.5590)$. The parameters F-EC; F-Salinity and F-TDS were positively correlated. In both the seasons, pre-monsoon and post-monsoon, the values indicate the association of calcium with bicarbonate, carbonate and fluoride. 
Table 3. Statistical summary of physicochemical parameters

\begin{tabular}{|c|c|c|c|c|c|c|c|c|c|c|c|c|c|c|}
\hline \multirow{2}{*}{ Parameters } & \multicolumn{7}{|c|}{ Pre-monsoon } & \multicolumn{7}{|c|}{ Post-monsoon } \\
\hline & Max. & Min. & Mean & Sum & SD & $\sigma^{2}$ & $\mathrm{CV}$ & Max. & Min. & Mean & Sum & $\mathrm{SD}$ & $\sigma^{2}$ & $\mathrm{CV}$ \\
\hline $\mathrm{pH}$ & 7.61 & 6.79 & 7.286 & 182.2 & 0.1782 & 0.0317 & 2.445 & 7.38 & 6.58 & 7.047 & 176.18 & 0.1649 & 0.0272 & 2.3401 \\
\hline EC & 1.47 & 0.351 & 0.783 & 19.6 & 0.3297 & 0.1087 & 42.111 & 1.372 & 0.222 & 0.697 & 17.426 & 0.3251 & 0.1057 & 46.6350 \\
\hline TA & 406.1 & 143.0 & 241.6 & 6040.8 & 78.0601 & 6093.38 & 32.305 & 400.3 & 138.8 & 232.5 & 5811.9 & 76.0684 & 5786.394 & 32.7210 \\
\hline Salinity & 368.8 & 82.1 & 213.2 & 5329.3 & 76.8163 & 5900.75 & 36.035 & 359.8 & 148.4 & 217.6 & 5440.7 & 65.5448 & 4296.122 & 30.1178 \\
\hline $\mathrm{CH}$ & 207.2 & 38.8 & 124.4 & 3109.5 & 50.9724 & 2598.19 & 40.981 & 219.03 & 49.9 & 131.8 & 3293.9 & 52.944 & 2803.137 & 40.1838 \\
\hline MH & 78.6 & 19.4 & 53.1 & 1328.4 & 17.2796 & 298.583 & 32.519 & 72.9 & 15.5 & 44.7 & 1117.8 & 16.883 & 285.0428 & 37.7599 \\
\hline $\mathrm{TH}$ & 285.2 & 81.3 & 177.5 & 4437.9 & 80.416 & 6466.733 & 45.3001 & 272.4 & 72.7 & 176.5 & 4411.7 & 61.404 & 3770.487 & 34.7963 \\
\hline TDS & 419.7 & 106.1 & 244.5 & 6112.8 & 84.1937 & 7088.576 & 34.433 & 422.6 & 182.9 & 281.2 & 7028.9 & 76.993 & 5928.049 & 27.3847 \\
\hline TSS & 151.8 & 39.9 & 73.7 & 1841.4 & 24.7474 & 612.4342 & 33.599 & 148.2 & 32.4 & 69.2 & 1729.8 & 24.99 & 624.8191 & 36.1261 \\
\hline TS & 491.0 & 146.0 & 318.2 & 7954.2 & 89.7876 & 8061.817 & 28.220 & 495.3 & 239.0 & 350.3 & 8758.7 & 80.8026 & 6529.053 & 23.0635 \\
\hline $\mathrm{F}$ & 1.7 & 0.2 & 0.8 & 19.4 & 0.4364 & 0.19044 & 56.266 & 1.6 & 0.15 & 0.7 & 17.5 & 0.4139 & 0.1713 & 59.0673 \\
\hline
\end{tabular}

Max. Maximum, Min. Minimum, SD Standard Deviation, $\sigma^{2}$ Square of standard deviation, CV coefficient of variance

Table 4. Karl pearson correlation matrix for water samples of Yercaud Taluk, Salem District during pre-monsoon season

\begin{tabular}{|c|c|c|c|c|c|c|c|c|c|c|c|}
\hline Parameters & $\mathrm{pH}$ & EC & TA & Salinity & $\mathrm{CH}$ & $\mathrm{MH}$ & $\mathrm{TH}$ & TDS & TSS & TS & Fluoride \\
\hline $\mathrm{pH}$ & 1 & & & & & & & & & & \\
\hline EC & 0.2019 & 1.0000 & & & & & & & & & \\
\hline TA & 0.0964 & 0.9209 & 1.0000 & & & & & & & & \\
\hline Salinity & 0.4239 & 0.8442 & 0.7350 & 1.0000 & & & & & & & \\
\hline $\mathrm{CH}$ & 0.5166 & 0.8102 & 0.6756 & 0.9163 & 1.0000 & & & & & & \\
\hline MH & 0.3627 & 0.4871 & 0.5119 & 0.5844 & 0.5190 & 1.0000 & & & & & \\
\hline $\mathrm{TH}$ & 0.5281 & 0.8059 & 0.7010 & 0.9206 & 0.9720 & 0.7052 & 1.0000 & & & & \\
\hline TDS & 0.4347 & 0.8799 & 0.7991 & 0.9876 & 0.9172 & 0.5849 & 0.9215 & 1.0000 & & & \\
\hline TSS & -0.0504 & 0.8481 & 0.1608 & 0.0846 & 0.1272 & 0.0398 & 0.1164 & 0.0866 & 1.0000 & & \\
\hline TS & 0.3937 & 0.8481 & 0.7937 & 0.9494 & 0.8951 & 0.5595 & 0.8962 & 0.9616 & 0.3568 & 1.0000 & \\
\hline $\mathrm{F}$ & 0.1572 & 0.7704 & 0.7491 & 0.6958 & 0.6663 & 0.5616 & 0.7069 & 0.7277 & 0.1529 & 0.7245 & 1.0000 \\
\hline
\end{tabular}


Table 5. Karl pearson correlation matrix for water samples of Yercaud Taluk, Salem District during post-monsoon season

\begin{tabular}{|c|c|c|c|c|c|c|c|c|c|c|c|}
\hline Parameters & $\mathrm{pH}$ & EC & TA & Salinity & $\mathrm{CH}$ & $\mathrm{MH}$ & $\mathrm{TH}$ & TDS & TSS & TS & Fluoride \\
\hline $\mathrm{pH}$ & 1 & & & & & & & & & & \\
\hline EC & 0.2188 & 1.0000 & & & & & & & & & \\
\hline TA & 0.0987 & 0.9240 & 1.0000 & & & & & & & & \\
\hline Salinity & 0.2036 & 0.9523 & 0.8776 & 1.0000 & & & & & & & \\
\hline $\mathrm{CH}$ & 0.2611 & 0.6221 & 0.5168 & 0.5518 & 1.0000 & & & & & & \\
\hline MH & 0.4377 & 0.5103 & 0.5787 & 0.4740 & 0.3817 & 1.0000 & & & & & \\
\hline $\mathrm{TH}$ & 0.2994 & 0.6767 & 0.6047 & 0.6061 & 0.9672 & 0.6040 & 1.0000 & & & & \\
\hline TDS & 0.1449 & 0.8722 & 0.7928 & 0.8763 & 0.7187 & 0.4883 & 0.7539 & 1.0000 & & & \\
\hline TSS & 0.0886 & 0.1158 & 0.2088 & -0.0129 & -0.0056 & -0.0079 & -0.0070 & -0.0062 & 1.0000 & & \\
\hline TS & 0.2776 & 0.8669 & 0.8201 & 0.8310 & 0.6831 & 0.4629 & 0.7162 & 0.9509 & 0.3035 & 1.0000 & \\
\hline F & 0.1788 & 0.7583 & 0.7425 & 0.6842 & 0.5590 & 0.5440 & 0.6315 & 0.7105 & 0.1706 & 0.7298 & 1.0000 \\
\hline
\end{tabular}


From Figure 1, it is found that WQI for 25 samples ranges from 7.61 to 90.18 . WQI has been registered about 32\% and 48\% under the excellent category (WQI $<25$ ) and $40 \%$ and $36 \%$ under good category (WQI $=25-50$ ). About $20 \%$ and $16 \%$ of water samples are poor in quality (WQI=51-75) during pre-monsoon and post-monsoon seasons. $8 \%$ of water samples are very poor during pre-monsoon season.

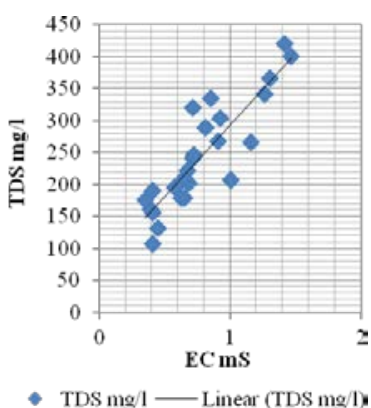

(a) Pre-monsoon period

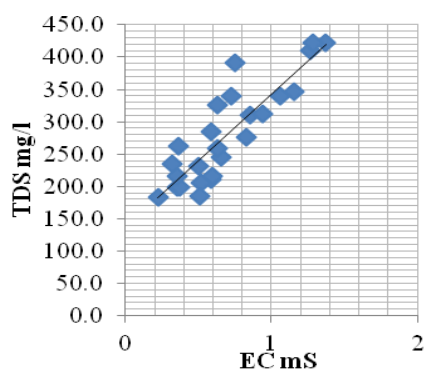

- TDS mg/l - Linear (TDS mo/l)

(b) Post-monsoon period

Figure 1(a) \& (b). Scatter diagrams shc ing correlation between EC and TDS during preand post-monsoon seasons

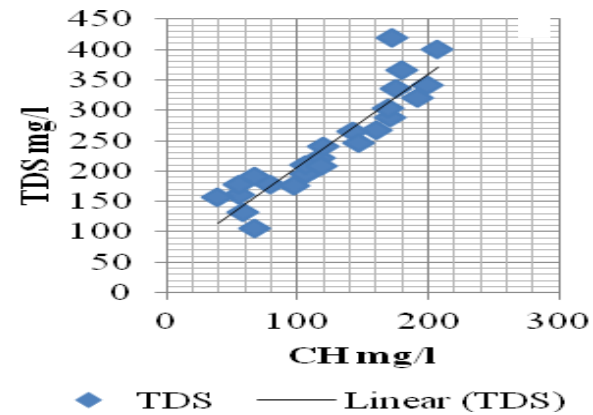

(a) Pre-monsoon period

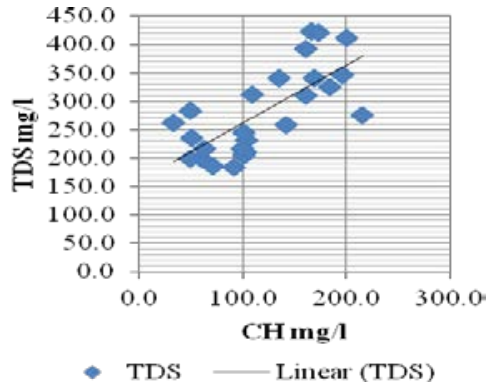

(b) Post-monsoon period

Figure 2(a) \& (b). Scatter diagrams showing correlation for $\mathrm{CH}$ and TDS during pre- and post-monsoon seasons

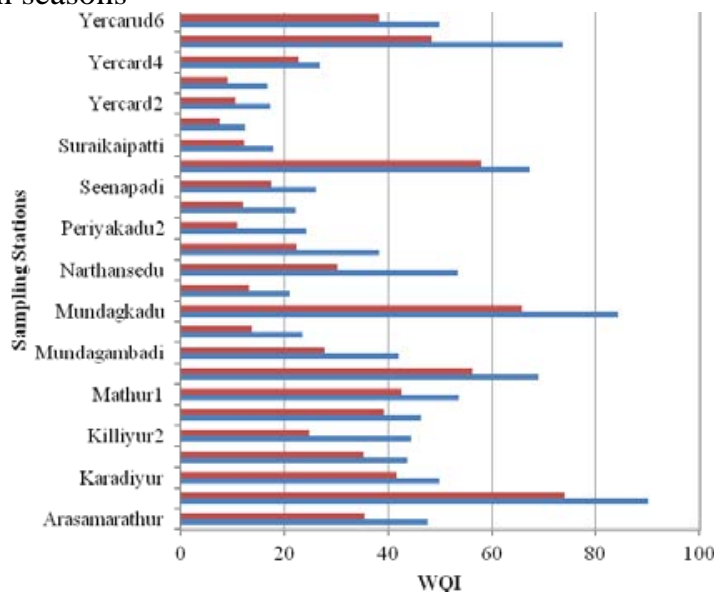

-WQI Post-monsoon

=1WQI Pre-monsoon

Figure 3. WQI for water samples of Yercaud Taluk in Salem District 


\section{Conclusion}

The present study was confined to Yercaud Taluk. The $\mathrm{pH}$ of water samples vary from slightly acidic to slightly alkaline. The influence of rain fall on the carbonate and bicarbonate ions of water samples was observed. The water samples were found to be moderately hard (36\% in pre-monsoon and $44 \%$ in post-monsoon) and hard nature (64\% in pre-monsoon and $52 \%$ in post-monsoon). The study reveals that all the villages have hardness within the desirable limit prescribed by WHO. The TDS values of total water samples of study area have been registered with $100 \%$ belonging to fresh type in both premonsoon and post-monsoon seasons. In the areas where the fluoride content of water is more than the permissible limit of $1.5 \mathrm{mg} / \mathrm{L}$ (WHO) defluoridation has to be done and supplied to the children and public. The rate of accumulation of fluoride in the human body can be reduced by calcium and phosphorous rich food ${ }^{26}$. The children and people those, who were affected by dental fluorosis, are to be recommended to take nutritional diet. As an essential nutrient in drinking water, Fluoride promotes dental health if it is between $0.5-1.5 \mathrm{mg} / \mathrm{L}$. But when it exceeds $1.5 \mathrm{mg} / \mathrm{L}$, it causes dental fluorosis. In the areas where the fluoride content of water is lower than the desirable limit of $0.5 \mathrm{mg} / \mathrm{L}$ (WHO) fluoridation has to be done and supplied to the children and public. It was found that the bore well and hand pump water samples ( 4 bore well water samples and 5 hand pump water samples) contain more fluoride than the open well, lake, falls and stream samples. From the Karl-Pearson correlation matrix, good correlation is observed between the parameters EC and Salinity, TDS, TSS, TS and also between CH and TH, TDS. The poor correlation is observed for TSS and other parameters except EC in pre-monsoon season. WQI has been registered about 32\% and 48\% under the excellent category (WQI < 25) and 40\% and 36\% under good category (WQI $=25-50$ ). About $20 \%$ and $16 \%$ of water samples are poor in quality (WQI=51-75) during pre-monsoon and post-monsoon seasons. $8 \%$ of water samples are very poor during pre-monsoon season.

\section{Acknowledgement}

The authors thank the Principals and Managements of St. Joseph's College (Autonomous), Tiruchirappalli and M.A.M. School of Engineering, Tiruchirappalli for encouragement and support.

\section{References}

1. Papatheodorou G, et al., Ecological Modelling, 2006, 193, 759-776.

2. Abbasi S A, Water quality Indices state-of-the art, center for pollution control and energy technology, Pondichery University, 1999.

3. World Health Organization, Guidelines for drinking water quality, $3^{\text {rd }}$ Edn., WHO, Geneva, 2006.

4. Kaplay R D and Patode H S, India Environ Geol., 2004, 46, 871-882.

5. Rima Chatterjee, Gourab Tarafder and Suman Paul, Bull Eng Geol Environ., 2010, 69, 137-141.

6. Ayeni A O, Balogun I I and Soneye A S O, Res J Environ Sci., 2011, 5(1), 21-33, DOI:10.3923/rjes.2011. 21.23.

7. Bullard W E, Effects of Land use on Water Resources in the Ecology of Man: An Ecosystem Approach, Smith R L, (Ed)., New York, Harper and Row Publisher, 1972.

8. Dewangan S, Vaishnav M M and Chandrakar P L and Korba C G, Rasayan J Chem., 2010, 3(4), 710-720. 
9. Dhirendra Mohan Joshi, Narendra Singh Bhandari, Alok Kumar and Namita Agrawal, Rasayan J Chem., 2009, 2(3), 579-587.

10. Navneet Kumar and Sinha D K, Int J Environ Sci., 2010, 1(2), 253-259.

11. Suhaimi - Othaman M, Ahmad A, Mushrifah I and Lim E C, Seasonal influence on water quality and heavy metal concentration in Tasik Chini, Peninsular Malaysia, Proceedings of Taal 2007: The $12^{\text {th }}$ World Lake Conference, 2007, 300-303.

12. Vassilis Z Antonopoulos, Dimitris M Papamichail and Konstantina A Mitsiou, Hydrology and Earth System Sciences, 2001, 5(4), 679-691.

13. Ramakrishnaiah C R, Sadashivaiah C and Ranganna G, E-J Chem., 2009, 6(2), 523-530.

14. Sami G Daraigan, Ahmed S Wahdain, Ahmed S Ba-Mosa and Manal H Obid, Int J Environ Sci., 2011, 1(7), 1692- 1701.

15. Papita Das Saha, Sengupta R, Jhuma Saha and Banerjee P K, Arch Environ Sci., 2012, 6, 34- 41.

16. Dadolahi-Sohrab A, Arjomand F and Fadaei-Nasab M, 2012, DOI: 10.1111/j. 17476593.2011.00303.x

17. Www.yercaudindia.com

18. APHA, Standard methods for the examination of water and wastewater, Washington, D C, American Public Health Association, 1998.

19. Tiwari T N and Mishra M, Indian J Environ Protect., 1985, 5(4), 276-279.

20. Karunakaran K, Thamilarasu P and Sharmila R, E-J Chem., 2009, 6(3), 909-914.

21. Sivasankar V and Ramachandramoorthy T, Environ Monit Assess., 2009, 156, 307-315. DOI:10.1007/s10661-008-0486-0.

22. Sawyer C N and McCarty P I, Chemistry for Sanitary Engineers ( $2^{\text {nd }}$ Ed.), New York, McGraw Hill, 1967.

23. Fetter C W, Applied hydrology, New Delhi, CBS, 1990.

24. Ramachandramoorthy T, Sivasankar V and Gomathi R, Fluoride and other Parametric Status of Ground water Samples at various locations of the Kolli Hills, Tamil Nadu, Indian J IPHE, 2010, 3.

25. Medikondu Kishore and Hanumantharao Y, Rasayan J Chem., 2010, 3(2), 341-346.

26. Janardhana Raju N, Sangita Dey and Kaushik Das, Current Science, 2009, 96(7), 979-985. 